\title{
Cannabinoids in the Treatment of Epilepsy: A Review
}

\begin{abstract}
Authors:
Daniel Zhou, Erin Dennis, Isha Snehal, *Arun Swaminathan

University of Nebraska Medical Center, Omaha, Nebraska, USA

*Correspondence to arun.swaminathan@unmc.edu

Disclosure: $\quad$ The authors have declared no conflicts of interest. This review was written in concordance with all ethical guidelines pertaining to research and the journal's guidelines as well.
\end{abstract}

Acknowledgements: The authors contributed equally to this work.

Received: $\quad 21.04 .21$

Accepted: $\quad 24.08 .21$

Keywords: $\quad$ Cannabinoids, epilepsy, innovation, treatment.

Citation: $\quad$ EMJ. 2021; DOI/10.33590/emj/21-000951

\begin{abstract}
Cannabinoids have been studied for their role in the treatment of epilepsy for many years. The U.S. Food and Drug Administration (FDA) approved them for the treatment of some refractory syndromes in 2018. Cannabidiol and tetrahydrocannabinol are the most commonly studied cannabinoids and have been studied in great depth vis-à-vis their pharmacokinetics and pharmacodynamics. Studies have shown the efficacy of cannabinoids in the treatment of refractory epilepsy. A substantial amount of research has been performed exploring the interactions between cannabinoids and other conventional antiseizure medications. The exact mechanisms by which cannabinoids exert their effects on seizure control remain unclear and research into these mechanisms continues in great earnest. Cognitive changes from cannabinoids are constantly being studied and add to potential benefits from the use of these compounds. Cultural and social misconceptions and roadblocks about the use of cannabinoids persist and represent an ongoing obstacle to increasing research and therapeutic use of these compounds. This review focuses on all these aspects and of the use of these cannabinoids in the treatment of epilepsy and seeks to offer a fairly comprehensive description of the facets of cannabinoid therapy for refractory epilepsy.
\end{abstract}

\section{INTRODUCTION}

Cannabidiol (CBD) comes from Cannabis sativa, which is a medicinal plant known to have several properties. Several types of extracts from cannabis can be broadly classified into psychotropic and non-psychotropic compounds, and CBD falls within the non-psychotropic compounds. In recent years, it has been found to be useful in several diseases such as Huntington's disease, amyotrophic lateral sclerosis, Parkinson's disease, and Alzheimer's disease. ${ }^{1-4}$
Cannabis has been in medicinal use for a long time, but it was first described in the United States Pharmacopoeia in $1850 .{ }^{5}$ However, on 25 th June 2018, Epidiolex ${ }^{\circledast}$ (cannabidiol) was the very first cannabis-derived drug that was approved for use. ${ }^{6}$ Sativex, which is also a derivative and is known as nabiximols, is approved as an adjunctive treatment in multiple sclerosis in several countries. ${ }^{7}$

People with epilepsy constitute $1 \%$ of the global disease burden of disease, affecting over 50 
million people worldwide. ${ }^{8}$ While there are several types of epilepsy, drug treatment-resistant epilepsy is defined as having failed at least 2 antiepileptic drugs (AEDs), which were tolerated and appropriately chosen to achieve sustained seizure freedom. ${ }^{9}$ Most types of epilepsy are managed with antiepileptic drugs but for severe drug-resistant epilepsy, other treatments are being explored; one being the use of CBD.

Initially, as the medicinal use of cannabis started being explored, there were hardly any trials and evidence of efficacy was unclear. Due to the abuse potential of cannabis, many states were hesitant to approve the cannabis containing CBD. Now, with more trials and evidence, the use of $C B D$ is being medically prescribed and distributed. Therefore, now more than ever, there is a need to increase awareness around appropriate use of $\mathrm{CBD}$ in various diseases, especially epilepsy.

The objectives of this review article are to describe the science behind the properties of CBD and tetrahydrocannabinol (THC), summarise the clinical trials and adverse effects to date and explore the future directions of treatment using CBD and THC.

\section{BASIC SCIENCE}

THC and CBD act via the endocannabinoid system. The endocannabinoid system is composed of $G$ protein-coupled receptors, endogenous cannabinoid (CB) receptor ligands such as $\mathrm{N}$-arachidonylethanolamine (anandamide) and 2-arachidonoylglycerol, and ligand metabolic enzymes such as fatty acid amide hydrolase and monoacylglycerol lipase. ${ }^{10} \mathrm{CB}$ receptors are part of the GPCR family. CB1 receptors are located primarily in central and peripheral neurons, and CB2 receptors predominantly in immune cells. ${ }^{10}$ The activation of the CB1 receptors prevents excessive neuronal excitation in the central nervous system by modulation of neurotransmitter release. ${ }^{10}$ They modulate release of various inhibitory as well as excitatory molecules (transmitters) such as $\mathrm{V}$-aminobutyric acid (GABA), noradrenaline, acetylcholine, dopamine, serotonin, and glutamate. ${ }^{10}$ Endocannabinoids also act as retrograde synaptic messengers. Certain neurotransmitters can cause increase in postsynaptic calcium, which can trigger synthesis and the release of endocannabinoid molecules into synapses, which then act on presynaptic $\mathrm{CB} 1$ to inhibit the release of neurotransmitters such as glutamate and GABA. ${ }^{10}$ THC has equal or higher affinity towards CB1 and CB2 receptors but has lower efficacy than the other phytocannabinoids. ${ }^{10}$

While the psychotropic agent THC acts on CB1 and CB2 receptors, CBD does not. However, its actions include inhibitory action on the orphan $\mathrm{G}$ protein-coupled receptor 55, equilibrative nucleoside transporter, and the transient receptor potential of melastatin type 8 channel. ${ }^{11}$ On the contrary, it enhances action of the 5 hydroxytryptamine receptor $1 \mathrm{~A}$ on the glycine receptors a3 and a1, and the transient receptor potential ankyrin type 1 channel. ${ }^{11}$ It has a bidirectional action on intracellular calcium. ${ }^{10}$

At higher concentrations, CBD exerts its excitatory effects on transient action potentials vanilloid Type 1 and Type 2 and on the nuclear peroxisome proliferator-activated receptor $\mathrm{Y}$ and inhibits cellular uptake and fatty acid amide hydrolase-catalysed degradation of anandamide. ${ }^{12}$

The complex combination of these receptorligand interactions has helped CBD emerge with antiepileptic, neuroprotective, and antiinflammatory properties.

\section{Pharmacokinetics}

\section{Absorption}

Inhaled cannabinoids exhibit similar pharmacokinetics to intravenous (IV) cannabinoid. After inhalation, peak plasma concentrations of both THC and CBD are attained rapidly (within 3-10 $\mathrm{min}$ ). ${ }^{13}$

\section{Bioavailability}

The bioavailability of THC has been found between $10-35 \%$. This could be attributed to inhalational characteristics, size of inhaled particles, and inter- and intra-subject variability. ${ }^{13}$ The inhaled version of CBD has 35\% bioavailability. ${ }^{13}$ The sublingual route is also noted to have much higher bioavailability than the oral form. ${ }^{14}$ Although less frequently used, the intravenous version of THC has found to have a higher bioavailability. ${ }^{13}$ 


\section{Half-life}

The mean half-life of CBD was reported as 1.1and 2.4-hours, following nebuliser and aerosol administration (20 mg). ${ }^{15,16}$

\section{Distribution}

THC is highly lipophilic. Upon delivery, it gets distributed in highly perfused regions first including the lung, heart, brain, and liver..$^{13}$ Mean volume of distribution was 2,520 L following IV administration. ${ }^{17}$ Apparent volume of distribution after oromucosal spray was $26,298,31,994$, and 28,312 L. $^{18}$ Volume of distribution of CBD via the IV route has been found to be 32.7 (8.6) L/ kg. ${ }^{16}$

\section{Metabolism}

Hydroxylation of THC at C9 by the hepatic Cytochrome P450 enzyme system leads to production of the equipotent metabolite 11 hydroxy- $\Delta^{9}-\mathrm{THC}$. Cytochrome P450 2C9, 2C19, and $3 \mathrm{~A} 4$ are involved in the oxidation of $\mathrm{THC}^{19}$ Phase II metabolism of the 11-Nor-9-carboxy$\Delta^{9}$-THC involves the addition of glucuronic acid and, less commonly, of sulfate, glutathione, amino acids, and fatty acids via the 11-carboxylic acids group. ${ }^{13}$

Although similar to THC, CBD undergoes oxidation of $\mathrm{C} 9$ to the alcohol and carboxylic acid and side-chain oxidation. ${ }^{13}$ Both THC and CBD are subjected to a significant first-pass effect; however, unlike THC, a large proportion of CBD is excreted, unchanged in the faeces. ${ }^{13}$

\section{Elimination}

Of the THC that gets excreted, $80-90 \%$ is excreted as hydroxylated and carboxylated metabolites within 5 days. ${ }^{20}$ More than $65 \%$ is excreted in the faeces, approximately $20 \%$ being eliminated in the urine. ${ }^{21}$

Ujváry et al. also reported that $16 \%$ of CBD administered IV was excreted in urine as unchanged and conjugated CBD in 72 hours. ${ }^{22}$ It was also observed that $33 \%$ of the initial CBD was mostly excreted as unchanged CBD, with metabolites such as mono- and di-hydroxylated and monocarboxylic derivatives of CBD in the faeces within 72 hours. ${ }^{22}$

Keeping the above properties in mind, it was found that cannabinoids have variable properties depending on the type of formulations that could be effective. To counter hurdles of first pass metabolism and poor water solubility or absorption, several synthetic compounds have been designed such as water-soluble CBD powders, self-emulsifying delivery systems, and encapsulation of CBD within gelatine matrix pellets. ${ }^{23}$

\section{CLINICAL STUDIES}

\section{Clinical Efficacy in Current Use}

To date, there have been five major Phase III randomised controlled trials (RCTs) and several open label, expanded access studies that evaluated the efficacy and safety of CBD (Tables 1 and 2).

Of the RCTs, two of them studied the safety and efficacy of CBD on Dravet syndrome (DS), two on Lennox-Gastaut syndrome (LGS), and one on epilepsy associated with tuberous sclerosis (TS). 24-28 All RCTs were double-blind and placebocontrolled and took place in multiple centres in the USA and Europe, with the TS trial also including patients from Australia. They all demonstrated a significant difference in percentage reduction of monthly seizure frequencies over the course of at least 3 months compared to the placebo. Two of the studies assessed efficacy, comparing doses of CBD at $10 \mathrm{mg} / \mathrm{kg} /$ day and $20 \mathrm{mg} / \mathrm{kg} /$ day for DS and LGS and found that both dosing groups demonstrated significantly increased efficacy in reducing seizures compared to the placebo but otherwise produced similar results compared to each other. ${ }^{25,27}$ Adverse effects were noted to be more frequent in the higher dose group. ${ }^{25,27}$ One study similarly compared doses of CBD at $25 \mathrm{mg} / \mathrm{kg} /$ day and $50 \mathrm{mg} / \mathrm{kg} /$ day for patients with TS, both of which reduced seizure frequency compared to the placebo but otherwise produced similar results compared to each other. ${ }^{28}$

Multiple open label and expanded access trials were also identified from the literature review that demonstrated reduction in seizures in patients with various treatment-resistant epilepsies (Table 2). Six of the studies evaluated add-on treatment of CBD for treatment-resistant epilepsy (TRE) in general, one for LGS, one for epilepsy associated with TS, and one for epileptic spasms. ${ }^{29-37}$ 
Table 1: Randomised controlled trials.

\begin{tabular}{|c|c|c|c|c|c|c|c|}
\hline Study & $\begin{array}{l}\text { Epilepsy } \\
\text { syndrome }\end{array}$ & $\begin{array}{l}\text { Treatment } \\
\text { group }\end{array}$ & $\mathrm{n}$ & Study period & Efficacy variable & Outcome & $\begin{array}{l}\text { Estimated } \\
\text { median } \\
\text { differences } \\
\text { (from placebo) }\end{array}$ \\
\hline \multirow[t]{2}{*}{$\begin{array}{l}\text { Devinsky et al., } \\
(2017)^{24}\end{array}$} & \multirow[t]{2}{*}{ DS } & $\begin{array}{l}\text { CBD, up to } 20 \\
\mathrm{mg} / \mathrm{kg} / \text { day } \\
\text { after } 2 \text { weeks }\end{array}$ & 61 & 14 weeks & $\begin{array}{l}\text { Median \% change } \\
\text { in monthly seizures }\end{array}$ & $\begin{array}{l}-38.9 \% \text { (range: } \\
-100-337 \text { ) }\end{array}$ & $\begin{array}{l}-22.8 \%(95 \% \\
C l:-41.1--5.4 ; \\
p=0.010)\end{array}$ \\
\hline & & Placebo & 59 & 14 weeks & $\begin{array}{l}\text { Median \% change } \\
\text { in monthly seizures }\end{array}$ & $\begin{array}{l}-13.3 \% \text { (range: } \\
-91.5-230)\end{array}$ & N/A \\
\hline \multirow[t]{3}{*}{$\begin{array}{l}\text { Miller et al., } \\
(2020)^{25}\end{array}$} & \multirow[t]{3}{*}{ DS } & $\begin{array}{l}\text { CBD, up to } 20 \\
\mathrm{mg} / \mathrm{kg} / \text { day } \\
\text { after } 2 \text { weeks }\end{array}$ & 67 & 14 weeks & $\begin{array}{l}\text { Median \% } \\
\text { reduction in } \\
\text { monthly seizures }\end{array}$ & $45.7 \%$ & $\begin{array}{l}25.7 \%(95 \% \\
\text { Cl: } 2.9-43.2 \% ; \\
p=0.030)\end{array}$ \\
\hline & & $\begin{array}{l}\text { CBD, up to } 10 \\
\mathrm{mg} / \mathrm{kg} / \text { day } \\
\text { after } 2 \text { weeks }\end{array}$ & 66 & 14 weeks & $\begin{array}{l}\text { Median \% } \\
\text { reduction in } \\
\text { monthly seizures }\end{array}$ & $48.7 \%$ & $\begin{array}{l}29.8 \%(95 \% \\
C l: 8.4-46.2 ; \\
p=0.010)\end{array}$ \\
\hline & & Placebo & 65 & 14 weeks & $\begin{array}{l}\text { Median \% } \\
\text { reduction in } \\
\text { monthly seizures }\end{array}$ & $26.9 \%$ & N/A \\
\hline \multirow[t]{2}{*}{$\begin{array}{l}\text { Thiele et al., } \\
(2018)^{26}\end{array}$} & \multirow[t]{2}{*}{ LGS } & $\begin{array}{l}\text { CBD, up to } 20 \\
\mathrm{mg} / \mathrm{kg} / \text { day } \\
\text { after } 2 \text { weeks }\end{array}$ & 86 & 14 weeks & $\begin{array}{l}\text { Median \% } \\
\text { reduction in } \\
\text { monthly drop } \\
\text { seizures }\end{array}$ & $\begin{array}{l}43.9 \% \text { (IQR: } \\
1.9-69.6)\end{array}$ & $\begin{array}{l}17.2 \%(95 \% \\
\mathrm{Cl}: 4.1-30.3 \\
p=0.010)\end{array}$ \\
\hline & & Placebo & 85 & 14 weeks & $\begin{array}{l}\text { Median \% } \\
\text { reduction in } \\
\text { monthly drop } \\
\text { seizures }\end{array}$ & $\begin{array}{l}\text { 21.8\% (IQR: } \\
1.7-45.7)\end{array}$ & N/A \\
\hline \multirow[t]{3}{*}{$\begin{array}{l}\text { Devinsky et al., } \\
(2018)^{27}\end{array}$} & \multirow[t]{3}{*}{ LGS } & $\begin{array}{l}\text { CBD, up to } 20 \\
\mathrm{mg} / \mathrm{kg} / \text { day } \\
\text { after } 2 \text { weeks }\end{array}$ & 76 & 14 weeks & $\begin{array}{l}\text { Median \% } \\
\text { reduction in } \\
\text { monthly drop } \\
\text { seizures }\end{array}$ & $41.9 \%$ & $\begin{array}{l}21.6 \%(95 \% \\
\text { Cl: } 6.7-34.8 ; \\
p=0.005)\end{array}$ \\
\hline & & $\begin{array}{l}\text { CBD, up to } 10 \\
\mathrm{mg} / \mathrm{kg} / \text { day } \\
\text { after } 2 \text { weeks }\end{array}$ & 73 & 14 weeks & $\begin{array}{l}\text { Median \% } \\
\text { reduction in } \\
\text { monthly drop } \\
\text { seizures }\end{array}$ & $37.2 \%$ & $\begin{array}{l}19.2 \%(95 \% \\
\mathrm{Cl}: 7.7-31.2 ; \\
p=0.002)\end{array}$ \\
\hline & & Placebo & 76 & 14 weeks & $\begin{array}{l}\text { Median \% } \\
\text { reduction in } \\
\text { monthly drop } \\
\text { seizures }\end{array}$ & $17.2 \%$ & N/A \\
\hline \multirow[t]{3}{*}{$\begin{array}{l}\text { Thiele et al., } \\
(2021)^{28}\end{array}$} & \multirow[t]{3}{*}{$\begin{array}{l}\text { Epilepsy } \\
\text { with TS }\end{array}$} & $\begin{array}{l}\text { CBD, up to } 50 \\
\mathrm{mg} / \mathrm{kg} / \text { day } \\
\text { after } 4 \text { weeks }\end{array}$ & 73 & 16 weeks & $\begin{array}{l}\text { Median \% } \\
\text { reduction in } \\
\text { monthly seizures }\end{array}$ & $\begin{array}{l}47.5 \%(95 \% \mathrm{Cl}: \\
39.0-54.8)\end{array}$ & $\begin{array}{l}28.5 \%(95 \% \\
\text { Cl: } 11.9-42.0 ; \\
p=0.002)\end{array}$ \\
\hline & & $\begin{array}{l}\text { CBD, up to } 25 \\
\mathrm{mg} / \mathrm{kg} / \text { day } \\
\text { after } 4 \text { weeks }\end{array}$ & 75 & 16 weeks & $\begin{array}{l}\text { Median \% } \\
\text { reduction in } \\
\text { monthly seizures }\end{array}$ & $\begin{array}{l}48.6 \%(95 \% \mathrm{Cl}: \\
40.4-55.8)\end{array}$ & $\begin{array}{l}30.1 \%(95 \% \\
\text { Cl: } 13.9-43.3 \\
p<0.001)\end{array}$ \\
\hline & & Placebo & 76 & 16 weeks & $\begin{array}{l}\text { Median \% } \\
\text { reduction in } \\
\text { monthly seizures }\end{array}$ & $\begin{array}{l}26.5 \%(95 \% \mathrm{Cl}: \\
14.9-36.5)\end{array}$ & N/A \\
\hline
\end{tabular}

CBD: cannabidiol; Cl: confidence interval; DS: Dravet syndrome; IQR: interquartile range; LGS: Lennox-Gastaut syndrome; TS: tuberous sclerosis. 
Table 2: Open-label studies.

\begin{tabular}{|c|c|c|c|c|c|c|}
\hline Study & $\begin{array}{l}\text { Epilepsy } \\
\text { syndrome or } \\
\text { aetiology }\end{array}$ & Treatment group & $\mathrm{n}$ & Study period & Efficacy variable & $\begin{array}{l}\text { Primary } \\
\text { outcome }\end{array}$ \\
\hline $\begin{array}{l}\text { Devinsky et al., } \\
(2016)^{29}\end{array}$ & TRE & $\begin{array}{l}\text { CBD, variable } \\
\text { dosing, up to } 50 \\
\text { mg/kg/day }\end{array}$ & 137 & 12 weeks & $\begin{array}{l}\text { Median \% reduction in } \\
\text { monthly motor seizures }\end{array}$ & $\begin{array}{l}\text { 36.5\% (IQR: } \\
0-64.7 \text { ) }\end{array}$ \\
\hline $\begin{array}{l}\text { Klotz et al., } \\
(2019)^{30}\end{array}$ & TRE & $\begin{array}{l}\text { CBD, titrated up } \\
\text { to } 18 \mathrm{mg} / \mathrm{kg} / \mathrm{day}\end{array}$ & 35 & 3 months & $\begin{array}{l}\text { Median \% reduction in } \\
\text { monthly motor seizures }\end{array}$ & $\begin{array}{l}\text { 40.0\% (IQR: } \\
18.2-58.5)\end{array}$ \\
\hline $\begin{array}{l}\text { Gaston et al., } \\
(2 \mathrm{O} 21)^{31}\end{array}$ & TRE & $\begin{array}{l}\text { CBD, variable } \\
\text { dosing, up to } 50 \\
\text { mg/kg/day }\end{array}$ & 169 & 6 months & $\begin{array}{l}\% \text { of patients who had } \\
\geq 50 \% \text { reduction in } \\
\text { seizures }\end{array}$ & $56.0 \%$ \\
\hline $\begin{array}{l}\text { Szaflarski et al., } \\
(2018)^{32}\end{array}$ & TRE & $\begin{array}{l}\text { CBD, variable } \\
\text { dosing, up to } 50 \\
\text { mg/kg/day }\end{array}$ & 132 & 12 weeks & $\begin{array}{l}\text { Mean \% reduction per } \\
\text { participant per } 2 \text {-week } \\
\text { period }\end{array}$ & $63.6 \%$ \\
\hline $\begin{array}{l}\text { D'Onofrio et al., } \\
(2 \mathrm{O} 2 \mathrm{O})^{33}\end{array}$ & TRE & $\begin{array}{l}\text { CBD, titrated up } \\
\text { slowly to } 10 \mathrm{mg} / \\
\text { kg/day after } 4 \\
\text { weeks }\end{array}$ & 125 & 6 months & $\begin{array}{l}\text { Total monthly seizure } \\
\text { frequency change }\end{array}$ & $\begin{array}{l}-41 \% \pm 37.5 \% \\
(S D)\end{array}$ \\
\hline $\begin{array}{l}\text { Sands et al., } \\
(2019)^{34}\end{array}$ & TRE & $\begin{array}{l}\text { CBD, titrated up } \\
\text { to } 25 \mathrm{mg} / \mathrm{kg} / \text { day }\end{array}$ & 26 & 3 months & $\begin{array}{l}\% \text { of patients who had } \\
\geq 50 \% \text { reduction in motor } \\
\text { seizures }\end{array}$ & $26.9 \%$ \\
\hline $\begin{array}{l}\text { Thiele et al., } \\
(2019)^{35}\end{array}$ & LGS & $\begin{array}{l}\text { CBD, variable } \\
\text { dosing up to } 30 \\
\mathrm{mg} / \mathrm{kg} / \text { day }\end{array}$ & 366 & 12 weeks & $\begin{array}{l}\text { Median \% reduction in } \\
\text { monthly drop seizures }\end{array}$ & $48.2 \%$ \\
\hline $\begin{array}{l}\text { Hess et al., } \\
(2016)^{36}\end{array}$ & TS & $\begin{array}{l}\text { CBD, variable } \\
\text { dosing, up to } 50 \\
\text { mg/kg/day }\end{array}$ & 18 & 3 months & $\begin{array}{l}\text { Median \% reduction in } \\
\text { weekly motor seizures }\end{array}$ & $\begin{array}{l}\text { 40.0\% (IQR: } \\
0-77.0)\end{array}$ \\
\hline $\begin{array}{l}\text { Herlopian et al., } \\
(2020)^{37}\end{array}$ & $\begin{array}{l}\text { Epileptic } \\
\text { spasms }\end{array}$ & $\begin{array}{l}\text { CBD, titrated up } \\
\text { to } 25 \mathrm{mg} / \mathrm{kg} / \text { day }\end{array}$ & 9 & 3 months & $\begin{array}{l}\text { Mean \% reduction in } \\
\text { weekly epileptic spasms }\end{array}$ & $0.59 \%$ \\
\hline \multirow[t]{4}{*}{$\begin{array}{l}\text { Devinsky et al., } \\
(2018)^{38}\end{array}$} & $\begin{array}{l}\text { Aicardi } \\
\text { syndrome }\end{array}$ & $\begin{array}{l}\text { CBD, variable } \\
\text { dosing, up to } 50 \\
\mathrm{mg} / \mathrm{kg} / \text { day }\end{array}$ & 14 & 48 weeks & $\begin{array}{l}\text { Median \% reduction } \\
\text { in monthly convulsive } \\
\text { seizures }\end{array}$ & $\begin{array}{l}59.2 \% \text { (IQR: } \\
45-86)\end{array}$ \\
\hline & CDKL5 & $\begin{array}{l}\text { CBD, variable } \\
\text { dosing, up to } 50 \\
\text { mg/kg/day }\end{array}$ & 17 & 48 weeks & $\begin{array}{l}\text { Median \% reduction } \\
\text { in monthly convulsive } \\
\text { seizures }\end{array}$ & $\begin{array}{l}59.7 \%(I Q R: \\
5-75)\end{array}$ \\
\hline & Doose & $\begin{array}{l}\text { CBD, variable } \\
\text { dosing, up to } 50 \\
\mathrm{mg} / \mathrm{kg} / \text { day }\end{array}$ & 7 & 48 weeks & $\begin{array}{l}\text { Median \% reduction } \\
\text { in monthly convulsive } \\
\text { seizures }\end{array}$ & $\begin{array}{l}28.8 \% \text { (IQR: } \\
-8-92)\end{array}$ \\
\hline & Dup15Q & $\begin{array}{l}\text { CBD, variable } \\
\text { dosing, up to } 50 \\
\text { mg/kg/day }\end{array}$ & 8 & 48 weeks & $\begin{array}{l}\text { Median \% reduction } \\
\text { in monthly convulsive } \\
\text { seizures }\end{array}$ & $\begin{array}{l}38.4 \% \text { (IQR: } \\
-13-88)\end{array}$ \\
\hline
\end{tabular}

CBD: cannabidiol;CDKL5: cyclin-dependent kinase-like 5; IQR: interquartile range; LGS: Lennox-Gastaut syndrome SD: standard deviation; TRE: treatment-resistant epilepsy; TS: tuberous sclerosis. 
One study was specific to epilepsies associated with Aicardi syndrome, cyclin-dependent kinaselike 5 (CDKL5) deficiency disorder, Doose syndrome, and Dup15Q syndrome. ${ }^{38}$ These studies took place in the USA and/or Europe. In Asia, one study retrospectively evaluated the use of CBD in 42 patients with DS or LGS in South Korea and found that $33.3 \%$ of patients who received $C B D$ at a dose of $10 \mathrm{mg} / \mathrm{kg} /$ day had at least a $50 \%$ reduction in seizure frequency after 3 months. ${ }^{39}$

\section{Combined Effects with Clobazam}

Additional studies have been performed to investigate the potential additive effects of CBD and clobazam (CLB). Using a mouse model, Anderson et al. showed that CBD and CLB can modulate the $G_{A B A}$ receptors to a greater extent when combined, providing a potential additive effect to their therapies, but did not act in a synergistic manner. ${ }^{40}$ In a Phase II clinical trial, VanLandingham et al. evaluated the levels of drug metabolites in blood samples of patients receiving concomitant $C B D$ and CLB and reported that there was no evidence of any drugdrug interaction between CBD and CLB, but CBD did increase one of the metabolites of CLB. ${ }^{41}$ This study determined that CBD at a dose of $20 \mathrm{mg} /$ $\mathrm{kg} /$ day had an acceptable safety profile while coadministered with CLB.

Gunning et al. performed a meta-analysis of the four RCTs that investigated CBD as addon therapy for LGS or DS and calculated that patients who received the CBD add-on therapy had a significant reduction in frequency of drop seizures in LGS (treatment ratio: 0.70; 95\% confidence interval ( $\mathrm{Cl}$ ): 0.62-0.80; $\mathrm{p}<0.0001$ ) and convulsive seizures in DS (treatment ratio: 0.71; 95\% Cl: 0.60-0.83; $\mathrm{p}<0.0001$ ) compared to placebo. ${ }^{42}$ They then performed a subgroup analysis of patients on CLB, demonstrating a similar reduction in frequency of drop seizures in LGS (treatment ratio: 0.56; $95 \% \mathrm{Cl}$ : 0.47$0.67 ; p<0.0001)$ and convulsive seizures in DS (treatment ration: 0.63; 95\% Cl: 0.52-0.77; $\mathrm{p}<0.0001)$ compared to placebo. ${ }^{42}$

Devinsky et al., as part of the project team that carried out the RCTs, also performed a metaanalysis of the same four RCTs and found that the $\mathrm{CBD}$ treatment groups with (treatment ratio: 0.51 ; $95 \% \mathrm{Cl}$ : 0.52-0.68: $\mathrm{p}<0.0001$ ) and without CLB (treatment ratio: 0.85; 95\% Cl: 0.73-0.98; $p=0.0226$ ) were more efficacious than the placebo group in average reduction in seizure frequency. ${ }^{43}$ Furthermore, they reported via logistic regression analysis that the odds ratio of patients yielding a $>50 \%$ reduction in seizures from baseline was 2.51 (95\% Cl: 1.693.71; $p<0.0001$ ) in the CBD group without CLB and 2.40 (95\% Cl: 1.38-4.16; $\mathrm{p}=0.0020$ ). ${ }^{43}$ The treatment ratio appeared to numerically favour the CBD group with CLB versus without CLB, but the odds ratios of achieving $>50 \%$ reduction in seizures were similar.

In a separate study, Savage et al. retrospectively analysed data from 47 patients with refractory epilepsy who received CBD therapy and compared the outcomes between those who had concomitant CLB $(n=32)$ and those who did not $(n=15)$, finding no significant difference in reduction of mean weekly seizure frequency between the two groups. ${ }^{44}$

\section{Investigations of CBD and Other Epilepsies}

\section{Infantile spasms}

There are some clinical data available for the use of CBD in infantile spasms. In a multicentre Phase Il clinical study, Hussain et al. reported that, of the 9 patients with infantile spasms refractory to vigabatrin and adrenocorticotropic hormone, after 2 weeks of receiving CBD titrated up to 20 $\mathrm{mg} / \mathrm{kg} /$ day, one of the patients achieved complete response to treatment. ${ }^{45}$ This was defined as freedom from infantile spasms or hypsarrhythmia on 24-hour video EEG monitoring on Day 14 of the treatment. Similarly, in an open-label study, Herlopian et al. reported that, of the 9 patients with epileptic spasms (as classified per the 2001 International League Against Epilepsy [ILAE] at the time) who received CBD titrated up to 25 $\mathrm{mg} / \mathrm{kg} /$ day, 3 of the patients were seizure-free and had resolution of the hypsarrhythmia pattern on video EEG after 2 months of treatment. ${ }^{37}$

\section{Genetic and developmental epilepsies}

Multiple preliminary clinical studies have been performed evaluating the use of CBD in other genetic and developmental treatment-resistant epilepsies as well. Devinsky et al. reported results of an open-label study using CBD for treatmentresistant epilepsy in patients with Aicardi 
syndrome, CDKL5 deficiency disorder, Doose syndrome, and Dup15q syndrome, reporting a 48-week median monthly convulsive seizure reduction of $59.2 \%, 59.7 \%, 28.8 \%$, and $38.8 \%$, respectively. ${ }^{38}$ Kuchenbuch et al. reported that 3 patients with SYNGAP1 epileptic encephalopathy had an average $85 \%$ monthly seizure reduction by Month 9 after receiving maximum doses of 10, 17, or $23 \mathrm{mg} / \mathrm{kg} /$ day. ${ }^{46}$ Poisson et al. studied the use of CBD titrated up to $30 \mathrm{mg} / \mathrm{kg} /$ day as add-on therapy in 4 patients with migrating focal seizures associated with KCNT1 mutations and found, while none of the patients following 12 weeks of treatment did not have a reduction in seizures, one of the patients had a reduced intensity of seizures. ${ }^{47}$ Kaplan et al. studied 4 paediatric patients with refractory seizures in Sturge-Weber syndrome who, at Week 14 reported an average $65 \%$ monthly reduction in seizures. ${ }^{48}$ Sands et al. reported results of an expanded access program using CBD in 26 children with various treatmentresistant epilepsies, mostly presumed to be genetic, of whom $26.9 \%$ had $a \geq 50 \%$ reduction in motor seizures following 3 months of treatment. ${ }^{34}$

\section{Adverse Effects}

The safety of CBD has also been extensively studied. In the five Phase III RCTs, there was a higher percentage of adverse events in the CBD groups compared to placebo groups. ${ }^{24-28}$ The most common adverse events attributed to CBD reported in these trials included somnolence, pyrexia, upper respiratory tract infection, vomiting, decreased appetite, and diarrhoea. ${ }^{24-28}$ Three of the RCTs mentioned that $3.5-12.0 \%$ of patients in the CBD treatment group who had liver transaminase levels 3 times greater than the upper limit of normal, resulting in withdrawal from the trial. ${ }^{24,25,27}$ The other two RCTs noted 13.4$18.9 \%$ of patients with elevated liver transaminase levels, most of whom were also taking valproic acid. $^{26,28}$ Despite these adverse events, most patients in the CBD treatment group were able to continue receiving $\mathrm{CBD}$ in at least the 14-16 week treatment periods of the study. The three RCTs that compared different doses of CBD also demonstrated a higher prevalence of adverse events with higher dose groups (around $90 \%$ of patients with at least $20 \mathrm{mg} / \mathrm{kg} /$ day and $100 \%$ of patients in the $50 \mathrm{mg} / \mathrm{kg} /$ day groups) without improved clinical efficacy. ${ }^{25,27,28}$
Beyond RCTs for epilepsy, Dos Santos et al. reported a review of 18 clinical trials that included CBD as a treatment group, reiterating the common adverse effects, as mentioned above. ${ }^{49}$ They also noted that the presence of elevated transaminases, pyrexia, and upper respiratory tract infections appeared to be more frequent in patients receiving $C B D$ as add-on therapy for seizures. ${ }^{49}$ This could be related to certain comorbidities involved or drug interactions with other antiseizure drugs. Indeed, multiple studies have demonstrated that CBD affects serum levels of multiple antiseizure drugs due to shared metabolic pathways. ${ }^{50-52}$

Given CBD's close relationship with marijuana, some studies have also investigated its cognitive effects. In one study, Gaston et al. evaluated 20 patients with TRE who received functional MRI ( $\mathrm{fMRI}$ ) before and $>2$ weeks after receiving CBD with titration up to $25 \mathrm{mg} / \mathrm{kg} /$ day, while testing immediate and delayed memory, and found that treatment in CBD resulted in no significant changes in working memory performance and significant increases in neural activity on functional MRI in regions associated with verbal memory and attention compared with healthy controls. ${ }^{53}$ The same study group also explored cognitive functioning after long-term use of CBD in both children and adults with TRE and, by using the National Institute of Health (NIH) Toolbox Cognition Batter test before and after 1 year of CBD use, there was no significant change in cognitive test performance. ${ }^{54,55}$

\section{DIFFICULTIES IN DEVELOPMENT AND USE}

\section{Adverse Effects and Drug-drug Interactions}

As discussed above, adverse effects and drugdrug interactions are a limiting factor in the initiation and continuation of CBD in some situations. Elevation in liver enzymes was the most common reason for discontinuation in the four RCTs for LGS and DS. Most, if not all, of these patients were on concurrent valproate, and there were no cases of drug induced-liver injury. ${ }^{42,49}$ Additionally, concomitant use of CBD and CLB has been associated with increased somnolence. This combination has also resulted in rare cases of pneumonia and respiratory failure, thought 
to be secondary to the CBD-induced increase in plasma CLB levels as opposed to CBD alone. ${ }^{43,49}$ Special attention should be paid to these interactions, especially in European populations where the use of CBD has only been approved as an adjunctive treatment with CLB. This regulatory caveat may yield to potential harm in this regard and does not allow for minimising AED burden in patients who could potentially respond to CBD independent of CLB. Studies have shown mixed results on the effects of $C B D$ on other AEDs, specifically having either no effect on or increasing levels of valproate and topiramate. ${ }^{49}$ There have also been some reported increases in the drug levels of rufinamide, zonisamide, eslicarbazepine, and brivaracetam. ${ }^{49,52,56}$ All of this must be taken into consideration when prescribing CBD to patients with TRE who, by definition, are already on multiple other AEDs. Further studies are needed to explore potential interactions between $\mathrm{CBD}$ and other AEDs in order to identify potential limitations on dose escalation, minimise adverse effects, and optimise seizure control and ultimately quality of life. ${ }^{57}$

\section{Stigmatisation}

In general, stigmatisation stemming from social, political, and legal factors has been a barrier to the investigation and prescribing of medical cannabis over the years. ${ }^{58}$ While CBD is not psychoactive, given its derivation from Cannabis sativa, this stigma still carries over and raises theoretical concerns, particularly regarding abuse potential. A single dose, randomised, crossover trial demonstrated that CBD had a significantly low abuse potential at both therapeutic and supratherapeutic doses as compared to alprazolam and dronabinol in a population of recreational polydrug users. ${ }^{59}$ This study also showed that CBD had no observable cognitive or psychomotor impairment in contrast to alprazolam.59 The growing body of evidence demonstrating the efficacy and safety of CBD in the treatment of epilepsy has effectively reduced this stigma among the medical community, though some reservations may remain among patients based on cultural, political, and religious ideals. For instance, as recreational use of marijuana is forbidden in Islam, despite religious scholars considering medical use of cannabis and its derivatives acceptable, cultural barriers to patients who are Muslims accepting this as a treatment option persist. ${ }^{60}$ A survey on patient experiences with stigmatisation related to the use of medical cannabis found negative views of cannabis as a recreational drug, associated criminal sanctions, and using cannabis in the context of vulnerability (i.e., illness, disability) to be contributory to their sentiments. ${ }^{61}$ Ideally, the increasing legalisation and normalisation of medical and recreational cannabis products throughout the world will help break down some of these barriers going forward.

\section{FUTURE DIRECTIONS}

\section{Further Understanding of Mechanism and Predicting Treatment Response}

As discussed above, the complete mechanism of action of CBD in the treatment of epilepsy is not fully understood. Some studies have examined the relationship between $\mathrm{CBD}$ and patterns of neural synchronisation, and how these can be used to predict treatment response. Anderson et al. demonstrated that CBD treatment responders, as evidenced by $>70 \%$ seizure reduction, had stronger network integration and segregation in $\beta$ frequencies compared with non-responders. ${ }^{62}$ This study also showed that higher CBD dosage was associated with stronger network integration and segregation in $\Delta, \theta$, and a frequencies. Larger studies are needed to identify whether these findings suggest that $\mathrm{CBD}$ is causing these stronger brain network dynamics, or rather if stronger network dynamics predispose to treatment response. More clarification on this may identify which patients would benefit most from treatment with CBD. Additionally, further study of pharmacogenomics could help distinguish which patients are most likely to respond to CBD and identify optimal CBD and AED combinations on a tailored, individualised basis. ${ }^{57}$

\section{Use in Other Types of Epilepsy}

Given the limited U.S. Food and Drug Administration (FDA) indications for use of pharmaceutical-grade CBD, it is not currently available for the majority of epilepsy disorders. More evidence is needed to elucidate the efficacy of CBD in these other types of epilepsy beyond LGS, DS, and TS. There are a few ongoing clinical trials further examining $\mathrm{CBD}$ in these groups, in 
addition to one more novel study examining use in electrical status epilepticus of sleep. ${ }^{63,64}$ A recent systematic review of open-label studies and reports of experimental off-label use of purified, plant-based CBD suggested effectiveness in multiple other epilepsy syndromes including CDKL5 deficiency disorder, Aicardi syndrome, Dup15q syndrome, Doose syndrome, SYNGAP1 encephalopathy, Sturge-Weber syndrome, and epilepsy with myoclonic absences. ${ }^{65}$ There is also anecdotal evidence supporting efficacy beyond epileptic encephalopathies as some patients successfully supplement their prescribed antiepileptic regimen with cannabis for improved seizure control. For example, a survey of patients at an Oregon tertiary care centre found a majority of these patients reported successful seizure reduction with use of both high-CBD strains and varied THC:CBD combination strains of cannabis. ${ }^{66}$ Given the risks associated with these products including psychoactive effects of THC and the method of ingestion, specifically smoking and vaping, these patients may benefit from a safer, regulated pharmaceuticalgrade CBD option for the maximisation of their epilepsy treatment.

\section{Antiepileptic Potential of Other Cannabinoids}

The therapeutic potential of other cannabinoids in epilepsy requires further evaluation. Cannabidivarin has anticonvulsant properties in animal models, specifically in acute seizure and status epilepticus and was recently evaluated in a Phase II clinical trial for focal seizures; however, it did not meet primary endpoint of percentage change in focal seizure frequency. ${ }^{56,67,68}$ Cannabigerol did not demonstrate anticonvulsant properties in a mouse model, despite voltage-gated sodium channel blockade. ${ }^{69}$ Tetrahydrocannabivarin has been shown to suppress seizure activity in rats. ${ }^{70}$ Cannabichromene and its related phytocannabinoids were recently demonstrated to have anticonvulsant properties in a DS mouse model. ${ }^{71}$ Other cannabinoids including cannabinol, cannabidiolic acid, and tetrahydrocannabinolic acid that have been researched for neuroprotective and therapeutic potential in other neurologic conditions have yet to be studied in epilepsy. ${ }^{72}$

There is also evidence to suggest benefit from combinations of cannabinoids. A recent observational meta-analysis showed that CBDrich cannabis extracts were over 4 times more potent as compared to purified CBD, such that the same therapeutic effect could be achieved with significantly lower doses. ${ }^{73}$ Mild and severe adverse effects were significantly lower with CBD-rich extracts as compared with purified CBD as well. These observations support hypotheses of a synergistic or 'entourage effect' of CBD, with other minor phytocannabinoids and suggest that plant-based CBD extracts could potentially be more efficacious and better tolerated than the currently approved purified CBD in the treatment of seizures.

\section{CONCLUSIONS}

CBD exhibits antiepileptic effects through complex actions at multiple receptors in the brain. Previously there was a deficiency of evidence to support its use in the treatment of epilepsy due to legal barriers. Now, there have been 5 RCTs and several other open-label trials demonstrating the efficacy of CBD in the treatment of LGS, DS, TS, and TRE. While these studies have yielded promising results, there were some doubts about whether this data suggested a synergistic effect of $C B D$ and CLB, or truly represented CBD efficacy independently. Several additional meta-analyses of the major RCTs have shown similar efficacy of CBD both concomitantly and independent of CLB, though this combination does cause increased adverse effects, particularly sedation. Going forward, as use of $\mathrm{CBD}$ in the treatment of TRE increases, there is much more to be discovered regarding the complete mechanism of action, how to predict treatment responders, use in other forms of epilepsy, and possibly increased therapeutic potential when combined with other cannabinoids. 


\section{References}

1. Consroe P et al. Controlled clinical trial of cannabidiol in Huntington's disease. Pharmacol Biochem Behav. 1991;40(3):701-8.

2. Rajan TS et al. Gingival stromal cells as an in vitro model: cannabidiol modulates genes linked with amyotrophic lateral sclerosis. J Cell Biochem. 2017;118(4):819-28.

3. Chagas MHN et al. Effects of cannabidiol in the treatment of patients with Parkinson's disease: an exploratory double-blind trial. Psychopharmacol. 2014;28(11):108898.

4. Watt G, Karl T. In vivo evidence for therapeutic properties of cannabidiol (CBD) for Alzheimer's disease. Front Pharmacol. 2017:8:20.

5. Bridgeman MB, Abazia DT. Medicinal cannabis: history, pharmacology, and implications for the acute care setting. P T. 2017;42(3):180-8.

6. Abu-Sawwa $\mathrm{R}$ et al. Emerging use of epidiolex (cannabidiol) in epilepsy. J Pediatr Pharmacol Ther. 2020;25(6):485-99.

7. Perras C. Sativex for the management of multiple sclerosis symptoms. Issues Emerg Health Technol. 2005;(72):1-4.

8. Murray CJL, Lopez AD (eds.) Global Comparative Assessments in the Health Sector: Disease Burden, Expenditures and Intervention Packages (1994) Geneva: World Health Organization.

9. Kwan P et al. Definition of drug resistant epilepsy: consensus proposal by the ad hoc Task Force of the ILAE commission on therapeutic strategies. Epilepsia. 2010;51(6):106977

10. Pertwee RG. The diverse $\mathrm{CB} 1$ and CB2 receptor pharmacology of three plant cannabinoids: $\Delta 9$ tetrahydrocannabinol, cannabidiol and $\triangle 9$-tetrahydrocannabivarin. $\mathrm{Br} \mathrm{J}$ Pharmacol. 2008;153(2):199-215.

11. Soderstrom $\mathrm{K}$ et al. Cannabinoids modulate neuronal activity and cancer by $\mathrm{CB} 1$ and $\mathrm{CB} 2$ receptorindependent mechanisms. Front Pharmacol. 2017;8:720.

12. Ibeas Bih $\mathrm{C}$ et al. Molecular targets of cannabidiol in neurological disorders. Neurotherapeutics. 2015;12(4):699730

13. Huestis MA. Human cannabinoid pharmacokinetics. Chem Biodivers. 2007;4(8):1770-804.

14. Grotenhermen F. Pharmacokinetics and pharmacodynamics of cannabinoids. Clin Pharmacokinet. 2003;42(4):327-60.

15. Guy GW, Robson PJ. A phase I, double blind, three-way crossover study to assess the pharmacokinetic profile of cannabis based medicine extract (CBME) administered sublingually in variant cannabinoid ratios in normal healthy male volunteers (GWPKO215). Journal of Cannabis Therapeutics. 2004;3(4):121 52

16. Millar SA et al. A systematic review on the pharmacokinetics of cannabidiol in humans. Front Pharmacol. 2018;9:1365.

17. Ohlsson A et al. Single-dose kinetics of deuterium-labelled cannabidiol in man after smoking and intravenous administration. Biomed Environ Mass Spectrom. 1986;13(2):77-83.

18. Stott CG et al. A phase I study to assess the single and multiple dose pharmacokinetics of THC/ CBD oromucosal spray. Eur J Clin Pharmacol. 2013;69(5):1135-47.

19. Matsunaga $T$ et al. Metabolism of $\Delta 9$ tetrahydrocannabinol by cytochrome P450 isozymes purified from hepatic microsomes of monkeys. Life Sci. 1995;56(23-4):2089-95.

20. Halldin MM et al. Identification of in vitro metabolites of delta 1-tetrahydrocannabinol formed by human livers. Drug Metab Dispos. 1982;10(4):297-301.

21. Wall $M$ et al. Metabolism, disposition, and kinetics of delta9-tetrahydrocannabinol in men and women. Clin Pharmacol Ther. 1983;34(3):352-63.

22. Ujváry I, Hanuš L. Human metabolites of cannabidiol: a review on their formation, biological activity, and relevance in therapy. Cannabis Cannabinoid Res. 2016;1(1):90-101.

23. Williams NNB et al. Comparison of five oral cannabidiol preparations in adult humans: pharmacokinetics, body composition, and heart rate variability. Pharmaceuticals (Basel). 2021;14(1):35

24. Devinsky $O$ et al. Trial of cannabidiol for drug-resistant seizures in the Dravet syndrome. N Engl J Med. 2017;376(21):2011-20.

25. Miller I et al. Dose-ranging effect of adjunctive oral cannabidiol vs placebo on convulsive seizure frequency in Dravet syndrome: a randomized clinical trial. JAMA Neurol. 2020;77(5):613-21.

26. Thiele $\mathrm{E}$ et al. Cannabidiol in patients with seizures associated with LennoxGastaut syndrome (GWPCARE4): a randomised, double-blind, placebocontrolled phase 3 trial. Lancet. 2018:391(10125):1085-96.

27. Devinsky $O$ et al. Effect of cannabidiol on drop seizures in the Lennox-Gastaut syndrome. N Engl J Med. 2018;378(20):1888-97.

28. Thiele EA et al. Add-on cannabidiol treatment for drug-resistant seizures in tuberous sclerosis complex: a placebo-controlled randomized clinical trial. JAMA Neurol. 2021;78(3):285-92

29. Devinsky $O$ et al. Cannabidiol in patients with treatment-resistant epilepsy: an open-label interventional trial. Lancet Neurol. 2016;15(3):270-8.

30. Klotz KA et al. Efficacy and tolerance of synthetic cannabidiol for treatment of drug resistant epilepsy. Front Neurol. 2019;10:1313.

31. Gaston TE et al. Long-term safety and efficacy of highly purified cannabidiol for treatment refractory epilepsy. Epilepsy Behav. 2021;117:107862.

32. Szaflarski JP et al. Cannabidio improves frequency and severity of seizures and reduces adverse events in an open-label add-on prospective study. Epilepsy Behav. 2018;87:131-6.

33. D'Onofrio $\mathrm{G}$ et al. Slow titration of cannabidiol add-on in drug-resistant epilepsies can improve safety with maintained efficacy in an open-label study. Front Neurol. 2020;11:829.

34. Sands TT et al. Long-term safety, tolerability, and efficacy of cannabidiol in children with refractory epilepsy: results from an expanded access program in the US. CNS Drugs. 2019;33(1):47-60

35. Thiele E et al. Cannabidiol in patients with Lennox-Gastaut syndrome: interim analysis of an openlabel extension study. Epilepsia. 2019;60(3):419-428.

36. Hess E et al. Cannabidiol as a new treatment for drug-resistant epilepsy in tuberous sclerosis complex. Epilepsia. 2016;57(10):1617-24

37. Herlopian A et al. Cannabidiol in treatment of refractory epileptic spasms: an open-label study. Epilepsy Behav. 2020;106:106988.

38. Devinsky $\mathrm{O}$ et al. Open-label use of highly purified CBD (Epidiolex ${ }^{\circledR}$ ) in patients with CDKL5 deficiency disorder and Aicardi, Dup15q, and Doose syndromes. Epilepsy Behav. 2018;86:131-7.

39. Koo CM et al. Cannabidiol for treating Lennox-Gastaut syndrome and Dravet syndrome in Korea. J Korean Med Sci. 2020;35(50):e427.

40. Anderson LL et al. Coadministered cannabidiol and clobazam: preclinical evidence for both pharmacodynamic and pharmacokinetic interactions. Epilepsia. 2019;60(11):2224-34

41. VanLandingham KE et al. A phase 2, double-blind, placebo-controlled trial to investigate potential drug-drug interactions between cannabidiol and clobazam. J Clin Pharmacol. 2020;60(10):1304-13.

42. Gunning B et al. Cannabidiol in conjunction with clobazam: analysis of four randomized controlled trials. 
Acta Neurol Scand. 2021;143(2):15463.

43. Devinsky O et al. Cannabidiol efficacy independent of clobazam: meta-analysis of four randomized controlled trials. Acta Neurol Scand. 2020;142(6):531-40.

44. Savage TE et al. Efficacy of cannabidiol in subjects with refractory epilepsy relative to concomitant use of clobazam. Epilepsy Res. 2020;160:106263.

45. Hussain S et al. Synthetic pharmaceutical grade cannabidiol for treatment of refractory infantile spasms: a multicenter phase-2 study. Epilepsy Behav. 2020;102:106826.

46. Kuchenbuch M et al. Add-on cannabidiol significantly decreases seizures in 3 patients with SYNGAP1 developmental and epileptic encephalopathy. Epilepsia Open. 2020;5(3):496-500.

47. Poisson $\mathrm{K}$ et al. Response to cannabidiol in epilepsy of infancy with migrating focal seizures associated with KCNT1 mutations: an open-label, prospective, interventional study. Eur J Paediatr Neurol. 2020;25:77-81.

48. Kaplan EH et al. Cannabidio treatment for refractory seizures in Sturge-Weber syndrome. Pediatr Neurol. 2017;71:18-23.

49. Dos Santos RG et al. Serious adverse effects of cannabidiol (CBD): a review of randomized controlled trials. Expert Opin Drug Metab Toxicol. 2020;16(6):517-26.

50. Patsalos $\mathrm{PN}$ et al. Clinical implications of trials investigating drug-drug interactions between cannabidiol and enzyme inducers or inhibitors or common antiseizure drugs. Epilepsia. 2020;61(9):1854-68

51. Balachandran P et al. Cannabidiol interactions with medications, illicit substances, and alcohol: a comprehensive review. J Gen Intern Med. 2021;36(7):2074-84

52. Gaston TE et al. Interactions between cannabidiol and commonly used antiepileptic drugs. Epilepsia.
2017;58(9):1586-92.

53. Gaston TE et al. Effects of highly purified cannabidiol (CBD) on fMRI of working memory in treatmentresistant epilepsy. Epilepsy Behav. 2020;112:107358.

54. Martin RC et al. Cognitive functioning following long-term cannabidiol use in adults with treatment-resistant epilepsy. Epilepsy Behav. 2019;97:10510.

55. Thompson MD et al. Cognitive function and adaptive skills after a one-year trial of cannabidiol (CBD) in a pediatric sample with treatmentresistant epilepsy. Epilepsy Behav. 2020;111:107299.

56. Morano A et al. Cannabinoids in the treatment of epilepsy: current status and future prospects. Neuropsychiatr Dis Treat. 2020;16:381-96.

57. Raucci $U$ et al. Cannabidiol treatment for refractory epilepsies in pediatrics. Front Pharmacol. 2020;11:586110.

58. Baron EP. Comprehensive review of medicinal marijuana, cannabinoids, and therapeutic implications in medicine and headache: what a long strange trip it's been ... Headache. 2015:55(6):885-916

59. Schoedel KA et al. Abuse potential assessment of cannabidiol (CBD) in recreational polydrug users: a randomized, double-blind, controlled trial. Epilepsy Behav. 2018:88:162-71.

60. Robinson D et al. Bridging the accessibility gap of cannabinoid medicine and Arabic culture. Rambam Maimonides Med J. 2020;11(1):e0010.

61. Bottorff JL et al. Perceptions of cannabis as a stigmatized medicine: a qualitative descriptive study. Harm Reduct J. 2013;10:2.

62. Anderson DE et al. Global brain network dynamics predict therapeutic responsiveness to cannabidiol treatment for refractory epilepsy. Brain Commun. 2020:2(2):fcaa140.

63. 63. Alves P et al. Cannabis sativa: much more beyond $\triangle 9$ tetrahydrocannabinol. Pharmacol Res. 2020;157:104822.

64. 64. Northwell Health. Efficacy of epidiolex in patients with electrica status epilepticus of sleep (ESES). NCT04721691. https://ClinicalTrials. gov/show/NCT04721691.

65. Lattanzi S et al. Highly purified cannabidiol for epilepsy treatment: a systematic review of epileptic conditions beyond Dravet syndrome and Lennox-Gastaut syndrome. CNS Drugs. 2021;35(3):265-81.

66. Kerr A et al. Marijuana use among patients with epilepsy at a tertiary care center. Epilepsy Behav. 2019;97:144-8.

67. De Caro $\mathrm{C}$ et al. The potential role of cannabinoids in epilepsy treatment. Expert Rev Neurother. 2017;17(11):1069-79.

68. GW Research Ltd. A study of GWP42006 in people with focal seizures - part B. NCTO2365610. https://ClinicalTrials.gov/show/ NCTO2365610.

69. Hill AJ et al. Voltage-gated sodium (NaV) channel blockade by plant cannabinoids does not confer anticonvulsant effects per se. Neurosci Lett. 2014:566:269-74.

70. Hill AJ et al. $\Delta^{9}-$

Tetrahydrocannabivarin suppresses in vitro epileptiform and in vivo seizure activity in adult rats. Epilepsia. 2010;51(8):1522-32

71. Anderson LL et al. Cannabichromene, related phytocannabinoids, and 5-fluoro-cannabichromene have anticonvulsant properties in a mouse model of Dravet syndrome. ACS Chem Neurosci. 2021;12(2):330-9.

72. Stone NL et al. A systematic review of minor phytocannabinoids with promising neuroprotective potential. Br J Pharmacol. 2020;177(19):433052.

73. Pamplona FA et al Potential clinica benefits of CBD-rich cannabis extracts over purified CBD in treatment-resistant epilepsy: observational data meta-analysis. Front Neurol. 2018:9:759. 